KS. GRZEGORZ BUJAK*-LUBLIN

\title{
SYNOD KIELECKI Z 1927 ROKU I JEGO WPLYW NA KSZTAŁTOWANIE ADMINISTRACJI DIECEZJALNEJ
}

Dotychczasowe badania historyczne nad synodami w Polsce skupiały się głównie na okresie przedrozbiorowym i posiadają swoją bogatą literaturę ${ }^{1}$. Okres II Rzeczypospolitej nie doczekał się dotychczas całościowego opracowania, mimo prowadzonych w tym zakresie badań szczegółowych, głównie przez historyków prawa kościelnego ${ }^{2}$. Tymczasem rola synodów w kształtowaniu centralnej administracji diecezjalnej w niepodległej Polsce była znaczna.

W wielu diecezjach synody odegrały ważną rolę w porządkowaniu administracji diecezjalnej, chociaż tylko nieliczne, jak synod łucki, określiły w statutach tak szczegółowe zagadnienia, jak np. procedura obiegu pism w kurii, czy archiwizacja dokumentów ${ }^{3}$. Natomiast synod podlaski, adaptując przepisy kodeksu o organizacji kurii stwierdził, że w skład kurii diecezjalnej wchodzą dwa wydziały: administracyjny i sąd duchowny. Równocześnie szczegółowo określił obowiązki i prawa urzędników, wyznaczając im ustawowo uprawnienia przekraczające minimum zagwarantowane w kodeksie. Tak np. wikariusz generalny w razie nieobecności biskupa w diecezji dłużej niż 7 dni uzyskiwał automatycznie na mocy statutu 29 wszystkie uprawnienia, co do których prawo kanoniczne wymagało specjalnej zgody biskupa ${ }^{4}$.

Synod diecezji kieleckiej z 1927 r. nie szedł tak daleko w tworzeniu ram praw-

${ }^{*}$ Ks. Grzegorz Bujak - doktor historii, adiunkt w Katedrze Ustroju i Administracji Polski Instytut Historii, Wydział Nauk Humanistycznych KUL.

${ }^{1}$ H. Wyczawski, Przygotowanie do studiów w archiwach kościelnych, Kalwaria Zebrzydowska 1989, s. 218-224; W. Wójcik, Ze studiów nad synodami polskimi, Lublin 1982, s. 185-225.

${ }^{2}$ Prawnicy badają najczęściej albo cały dorobek synodów, szczególnie w zakresie recepcji prawa powszechnego na gruncie lokalnym, albo wybranych aspektów i ich uregulowań w prawie synodalnym. Por. M. Polak, Synod diecezjalny w Sandomierzu w 1923 roku. Studium historyczno-prawne, Lublin 2001, mps w Archiwum KUL; M. Kaleta, Eucharystia w ustawodawstwie synodalnym archidiecezji lwowskiej obrzqdku łacińskiego, Lublin 2007, mps w Archiwum KUL.

${ }^{3}$ M. Dębowska, Organizacja kurii biskupiej w Łucku. Studium kancelaryjno - archiwoznawcze, „Archiwa, Biblioteki i Muzea Kościelne”, 71 (1999), s. 484.

${ }^{4}$ Synod Diecezjalny Podlaski [...] w. d. 28, 29 i 30 sierpnia odbyty, Siedlce 1923, s.100-109. 
nych dla działalności administracyjnej. Jego statuty stanowiły w tym zakresie podsumowanie długoletniej praktyki zarządzania diecezją, $\mathrm{w}$ tym dziewięcioletniej w niepodległym państwie.

Synod odbył się w dniach 5 do 7 lipca $1927 \mathrm{r}^{5}$. Znaczną ilość czasu w trakcie synodu pochłaniały uroczystości liturgiczne oraz przewidziana przepisami kościelnymi i regulaminem forma zewnętrzna. Każdego dnia o godz. 7 rozpoczynała się procesja uczestników do katedry, gdzie o godz. 8 odprawiano Mszę św. i biskup wygłaszał stosowne kazanie. W pierwszym dniu uczestnicy odśpiewali hymn do Ducha Świętego i złożyli wyznanie wiary oraz przewidziane prawem przysięgi w tym antymodernistyczną. Dopiero po zakończeniu części liturgicznej w pierwszym i drugim dniu odbywały się obrady synodu w budynku seminarium od godziny 10.30 do 13.30 i od 15.40 do 18.40 . W trzecim i ostatnim dniu, podczas uroczystego nabożeństwa porannego w katedrze, miało miejsce przyjęcie statutów synodalnych i zamknięcie obrad ${ }^{6}$.

Przebieg obrad był określony regulaminem. W czasie obrad odczytywano projekty statutów, do których można było zgłaszać poprawki. Dyskusja dozwolona była tylko podczas zebrań w seminarium. Można było zgłaszać także protesty odnośnie do treści statutów. $Z$ zachowanych akt wynika jednak, że nikt nie skorzystał z tej możliwości ${ }^{7}$. W synodzie wzięło udział 116 duchownych wezwanych przez biskupa z urzędu oraz wybranych przez księży. W ich gronie znalazło się 12 kanoników kapituły kieleckiej, 8 kapituły wiślickiej, 8 przedstawicieli seminarium duchownego, 3 urzędników kurii, 15 dziekanów, 3 prefektów, 50 proboszczów, 15 wikariuszy i 2 przedstawicieli zakonów ${ }^{8}$.

Ponieważ obrady synodu ze względu na swój charakter miały w znacznej mierze przebieg formalny, dlatego zasadniczy proces tworzenia statutów synodalnych przebiegał $\mathrm{w}$ fazie przygotowawczej, a znaczny udział duchowieństwa $\mathrm{w}$ tych działaniach sprawił, że w czasie obrad bez problemów przyjmowano uzgodnione wcześniej teksty. Jeszcze w 1925 r. władza diecezjalna zachęciła księży, by na konferencjach dekanalnych podjęli dyskusję nad problematyką synodalną. $Z$ wielu dekanatów napłynęły wówczas do kurii protokoły z wnioskami, w których księża poruszyli olbrzymią liczbę spraw związanych z całokształtem funkcjonowania diecezji. Dają one szeroki obraz problemów duszpasterskich, administracyjnych, liturgicznych, a także społecznych, w obliczu których stawali księża w diecezji kieleckiej w pierwszych latach niepodległości.

Najobszerniejszy protokół z odbytej w 1925 r. konferencji, przesłali księża $\mathrm{z}$ dekanatu irządzkiego, a jego treść jest w znacznej mierze reprezentatywna dla kierunku dyskusji i poglądów duchowieństwa kieleckiego. W sprawach liturgicznych postulowano rozszerzenie używania języka polskiego w nabożeństwach. Chodziło o możliwości odprawiania nieszporów z ludem po polsku. Postulowano także zakazanie księżom wprowadzania $\mathrm{w}$ parafiach własną powagą różnych praktyk dewocyjnych oraz ograniczenie trwania czasu sumy niedzielnej do naj-

\footnotetext{
${ }^{5}$ Archiwum Diecezjalne w Kielcach (dalej ADK), sygn. OR 4/1, k. 46-47.

${ }^{6}$ ADK, sygn. OR 4/1, k. 1.

${ }^{7}$ ADK, sygn. OR $4 / 1$, k. 2.

${ }^{8}$ Synodus Dioecesana Kielcensis 1927, Kielce brw., s. 36-39.
} 
wyżej 1,5 godziny. Księża widzieli także potrzebę przenoszenia na niedzielę obchodów świąt zniesionych. Stwierdzali, że praktyka odbywania ślubów w soboty i niedziele jest niepożądana, chcieli móc organizować nabożeństwa różańcowe w porze rannej, a nie jak to przewidywały przepisy diecezjalne - wieczorem. Widzieli też potrzebę opracowania jednolitego rytuału nabożeństw, a przede wszystkim różańca, by przezwyciężać różne lokalne praktyki. W stosunku do centralnej administracji diecezjalnej domagali się zachowywania przez pracowników kurii tajemnicy służbowej, szczególnie w sprawach personalnych. Domagali się, by wypłacając pensje rządowe, kuria wyszczególniała wszystkie potrącenia, jakich dokonywała. Chcieli też poprawy swojej sytuacji materialnej, między innymi poprzez możliwość wpisywania w koszty funkcjonowania parafii wydatków ponoszonych „w interesie parafii”, chodziło głównie o koszty urządzania odpustów. Domagali się dopuszczenia wikariuszy do dokumentacji finansowej parafii, przede wszystkim do rozliczeń iura stolae. W kwestiach związanych z dyscypliną kleru postulowali wspólne stołowanie wikariuszy i proboszczów, wydanie księżom zakazu tańczenia nawet $\mathrm{w}$ domach najbardziej zaufanych parafian, a także gry w karty w lokalach publicznych. Postulowali też zniesienie obowiązującego w diecezji pod karą suspensy zakazu jazdy na rowerze, wskazując na rolę tego środka lokomocji w duszpasterstwie. W sprawach związanych z życiem parafii postulowali przeprowadzenie w całej diecezji misji, ograniczenia rezerwacji biskupich związanych $\mathrm{z}$ odbywaniem sakramentu pokuty, ograniczenia udziału świeckich w zarządzie majątkiem parafialnym. Pod adresem funkcjonowania seminarium duchownego wysuwali postulat większego związania programu nauczania z duszpasterstwem, poprawę wyżywienia kleryków, aby: „zamiast $80 \%$ chorych, wychodziło z seminarium $80 \%$ zdrowych księży"

Podobne postulaty znajdujemy w protokołach innych konferencji dekanalnych poświęconych przygotowaniom synodalnym. W Nowym Korczynie na przykład 13 października 1926 r. księża postulowali między innymi, aby władza diecezjalna częściej brała księży w obronę w czasie sporów z władzami oświatowymi i podatkowymi, aby ogłoszony został wykaz probostw nieusuwalnych i lista „parafii sąsiedzkich”, tzn. takich, których proboszczowie mieli prawo i obowiązek wzajemnego zastępstwa w razie nagłej potrzeby ${ }^{10}$.

Jak zatem widać największa część zgłaszanych postulatów dotyczyła spraw związanych z codziennymi problemami funkcjonowania parafii. I chociaż nie wszystkie znalazły odzwierciedlenie w treści statutów synodalnych z 1927 r., to jednak świadczą o znacznym zaangażowaniu duchowieństwa parafialnego w dyskusje przedsynodalne i odzwierciedlają problemy z jakimi borykali się na co dzień księża $\mathrm{w}$ pracy administracyjnej i duszpasterskiej.

Kolejnym etapem procedury przygotowania synodu było powołanie przez biskupa 29 grudnia 1926 r. komisji synodalnych, nadanie im regulaminu i wyznaczenie zadań. Komisji było 10. Nad koordynacją prac czuwać miała komisja główna, przewodniczył jej wikariusz biskupi ks. B. Czerkiewicz, w jej skład wchodzili przewodniczący wszystkich pozostałych 9 komisji, referenci i radcy.

\footnotetext{
${ }^{9}$ ADK, sygn. OR 4/1, k. 70-75.

${ }^{10}$ ADK, sygn. OR 4/1, k. 59.
} 
Poza pracami koordynacyjnymi miała ona opracować statuty dotyczące kurii, kapituł, seminarium, oraz przygotować ostateczną redakcję wszystkich dokumentów przedstawionych synodowi ${ }^{11}$.

Każdej z pozostałych 9 komisji przydzielono do opracowania projekty wyznaczonych statutów synodalnych oraz łączących się z nimi tematycznie aneksów. Tak np. komisja do spraw kleru miała opracować statuty o prawach, przywilejach i obowiązkach duchownych, uwzględniając zróżnicowanie na dziekanów, proboszczów i wikariuszy, określić zasady tworzenia nowych parafii. Ponadto jako aneksy instrukcje: o zasadach współpracy wikariuszy i proboszczów, o wizytacji biskupiej i dziekańskiej, o konferencjach dekanalnych. Natomiast komisja sakramentalna miała przygotować statuty dotyczące udzielania sakramentów, a jako aneksy kwestionariusz badań przedślubnych i instrukcję o stwierdzeniu stanu wolnego, o dyspensach małżeńskich, o małżeństwach mieszanych, o cenzurach kościelnych i rezerwacjach w sprawowaniu sakramentu pokuty. Komisja pastersko-społeczna miała opracować statuty o działalności pasterskiej, społecznej i sprawach publicznych, o książkach i czasopismach, a jako aneks instrukcję o odbywaniu kolędy. Natomiast komisja bracka statuty o organizacjach wiernych i aneks zawierający wzorcowe statuty bractwa i stowarzyszenia religijnego ${ }^{12}$.

Dnia 4 stycznia 1927 r. biskup wysłał listy do przewodniczących komisji, zobowiązując ich do odbycia zasadniczych posiedzeń w styczniu i lutym oraz przygotowania na nich wyznaczonych projektów ${ }^{13}$. Obrady komisji miały się odbywać w seminarium duchownym a ich terminarz został ogłoszony w „Kieleckim Przeglądzie Diecezjalnym". Poza członkami komisji na zebrania mieli przybyć księża wezwani specjalnie przez kurię oraz delegaci z dekanatów. Prawo to zostało również przyznane bez ograniczeń wszystkim księżom, którzy z jakichkolwiek powodów interesowali się $\mathrm{w}$ sposób szczególny pracami danej komisji ${ }^{14}$. Stworzenie tak szerokich możliwości wzięcia udziału w dyskusji nad projektami statutów synodalnych na ich etapie wstępnym dawało możliwość wypowiedzi wszystkim księżom i przedyskutowania odpowiednio wcześniej zgłaszanych poprawek i wniosków. W wyniku prac komisji w I połowie 1927 r. zostały przygotowane projekty dokumentów synodalnych, przedstawionych pod obrady $\mathrm{w}$ lipcu $1927 \mathrm{r}^{15}$. Przedłożone projekty zostały przyjęte bez zmian merytorycznych i ogłoszone w dniu zamknięcia 7 lipca $1927 \mathrm{r}$.

Przyjęte statuty synodalne dzieliły się na 2 działy: o osobach i o rzeczach. Statuty o osobach w cześci pierwszej regulowały prawa i przywileje oraz, osobno, obowiązki duchownych. Następnie omówiono szczegółowe przepisy o funkcjonowaniu: kurii, kapituł, dziekanów, proboszczów, wikariuszy parafialnych oraz rektorów kościołów. W części drugiej precyzowano przepisy dotyczące zakonników, a w części trzeciej o wierze i obyczajach znajdowały się ustalenia synodu dotyczące w sposób szczególny świeckich. Znalazły się tu między innymi zalece-

\footnotetext{
${ }^{11}$ ADK, sygn. OR 4/2, k. 51.

${ }^{12}$ ADK, sygn. OR 4/2, k. 48.

${ }^{13}$ ADK, sygn. OR 4/2, k. 53.

${ }^{14}$ „Kielecki Przegląd Diecezjalny”, 14 (1927) s. 24-25.

${ }^{15}$ ADK, sygn. OR 4/1, k. 27.
} 
nia o zwalczaniu masonerii, socjalizmu oraz sekciarstwa. W ocenie stanu moralnego wiernych wskazano na spowodowany wojną upadek obyczajów. W celu poprawy moralności wiernych postanowiono szczególną troską otoczyć rodzinę, zalecono przeciwstawianie się rozwiązłości i aborcji ${ }^{16}$.

W dziale o rzeczach zamieszczone zostały przepisy dotyczące udzielania sakramentów, organizacji cmentarzy, odprawiania nabożeństw, działalności duszpasterskiej z różnymi grupami wiernych, oraz beneficjach.

Jak wynika z przedstawionych powyżej danych, postanowienia synodu z $1927 \mathrm{r}$. miały $\mathrm{w}$ znacznej mierze charakter duszpasterski i tylko w niewielkim stopniu poruszały problemy związane $\mathrm{z}$ administracyjnymi aspektami funkcjonowania diecezji. Stosunkowo dużo uwagi poświęcono tym problemom w dziale o osobach. Omawiając rolę w administracji kurii, dekanatów i parafii, ograniczono się do powtórzenia odpowiednich kanonów kodeksu z $1917 \mathrm{r}$.

Synod wymienił urzędników kurii i ogłosił wykaz komisji kurialnych. Nie określił jednak zasad ich funkcjonowania ani zakresu kompetencji, stwierdzając jedynie, że kierują się one własnymi statutami i regulaminami ${ }^{17}$. W aneksach synodalnych został zamieszczony „Regulamin diecezjalny dla spraw organistowskich", który określił procedury działania diecezjalnej komisji organistowskiej, wchodzącej w skład kurii ${ }^{18}$. W tym samym czasie statuty synodalne innych innych diecezji określały także procedury działania centralnych urzędów diecezjalnych. W diecezji łuckiej i podlaskiej rozgraniczono zakres kompetencji urzędników ordynariatu i komisji kurialnych, sprecyzowano drogę służbową i tryb podejmowania decyzji, wskazując $w$ jakich dziedzinach poszczególne urzędy miały głos decydujący, a w jakich jedynie doradczy ${ }^{19}$. Warto jednak zaznaczyć, że nie we wszystkich diecezjach synody podejmowały problemy funkcjonowania administracji centralnej. Tak np. w statutach synodu archidiecezji warszawskiej z 1922 r. brak było w ogóle postanowień o organizacji kurii biskupiej ${ }^{20}$. Podobnie było $\mathrm{w}$ postanowieniach synodu tarnowskiego z $1928 \mathrm{r}^{21}$. Poświęcono $\mathrm{w}$ nim jednak więcej uwagi, pominiętemu w statutach archidiecezji warszawskiej, zagadnieniu funkcjonowania urzędu dziekańskiego. Sprecyzowano bowiem obowiązki dziekanów w stosunku do biskupa i kurii oraz uprawnienia w stosunku do duchowieństwa dekanalnego 22 .

I synod kielecki najwięcej uwagi poświęcił sprawom administracyjnym w załączonych do dekretów synodalnych instrukcjach o wizytacjach kanonicznych dziekańskiej i biskupiej. W instrukcji o wizytacji dziekańskiej określono zakres uprawnień kontrolnych dziekanów w stosunku do podległych im parafii, tryb sporządzania sprawozdań wizytacyjnych i przekazywania ich do kuriii ${ }^{23}$.

\footnotetext{
${ }^{16}$ Synodu dioeceana Kielcensiss, s. 109-110.

${ }^{17}$ Tamże, s. 65.

${ }^{18}$ Tamże, s. 271-272.

${ }^{19}$ Synod Diecezjalny Podlaski, s. 100-109; Dębowska, Organizacja kurii biskupiej, s. 484-

${ }^{20}$ Por. Synodus Archidioecesana Varsaviensis [...] celebrata, Warszawa 1922.

${ }^{21}$ Por. Pierwszy synod diecezji tarnowskiej1928, Tarnów 1928.

${ }^{22}$ Tamże, s. 71-72.

${ }^{23}$ Synodus dioecesana Kielcensis, s. 248-254.
} 485. 
W instrukcji „W sprawie korespondencji z władzami” ustalono drogę służbową załatwiania przez księży spraw z urzędami państwowymi. Kontakty z władzami świeckimi w sprawach urzędu kościelnego (parafialnego), beneficjum lub kościoła miały się odbywać za pośrednictwem kurii. Bezpośrednia korespondencja dozwolona była tylko $\mathrm{w}$ sprawach związanych $\mathrm{z}$ prowadzeniem przez parafie ksiag metrykalnych (wypisy, statystyki itp.) oraz w sprawach, w których duchowny występował jako osoba prywatna ${ }^{24}$. Kompetencje rad kościelnych (parafialnych) określała instrukcja „O radzie kościelnej i zgromadzeniu parafialnym”. Poddano je silnemu nadzorowi proboszczów, ale równocześnie przyznano uprawnienia w zakresie najmowania służby kościelnej, w tym także organistów ${ }^{25}$.

Jak wynika $\mathrm{z}$ analizy dokumentów synodalnych procedury administracyjne zostały w nich uwzględnione w stopniu minimalnym. Funkcjonowanie instytucji kościelnych, tak centralnych jak i terenowych, opierało się na dotychczasowej praktyce i odrębnych instrukcjach wydawanych przez władzę diecezjalną w zależności od potrzeb.

\section{DIE SYNODE VON KIELCE IM JAHRE 1927 UND IHR EINFLUSS AUF DIE GESTALTUNG DER DIÖZESANVERWALTUNG}

\section{Zusammenfassung}

In den Jahren 1918-1939 fanden, nach langer Pause infolge der Aufteilung Polens unter die Nachbarmächte, in vielen Diözesen wieder Synoden statt. Eines der dort behandelten Probleme, wenn auch nicht das wichtigste, betraf die Frage der Diözesanverwaltung auf zentraler und Pfarreiebene. Vorliegender Artikel behandelt die Organisation und den Verlauf der Synode von Kielce im Jahre 1927 mit besonderer Berücksichtigung eben dieser Fragen. Die Erfolge von Kielce auf diesem Gebiet wurden mit den Ergebnissen einiger anderer ausgewählter Synoden verglichen. Auf ihrem Hintergrund präsentieren sich die Beschlüsse der Synode von Kielce nicht gerade imponierend. Dies bildete jedoch keine Ausnahme, im Gegenteil, denn nur selten befasste man sich mit Fragen der Verwaltung so ausführlich wie auf den Synoden von Luck und Podlasie. Es braucht nur daran erinnert zu werden, dass diese Problematik zum Beispiel in den Beschlüssen der Synode von Warschau überhaupt kein Echo fanden.

\footnotetext{
${ }^{24}$ Tamże, s. 260.

${ }^{25}$ Tamże, s. 270.
} 